\title{
Electronic Distance Education (EDE) New Mantra for Future Progress
}

\author{
Dr. Abha Singh ${ }^{1}$, Dr. Priya Soni Khare ${ }^{2}$ \\ ${ }^{1}$ Sr. Lecturer, Education Department, C. M. P. Degree College, Allahabad \\ ${ }^{2}$ Assistant Professor, B.Ed Department, Banasthali Vidyapith, Rajasthan
}

\begin{abstract}
India is passing through a very critical phase of development and facing the challenge posted by rapidly changing technology and market environment. Today student feel school is not challenging or interactive enough. E-learning has brought back the joy of learning through its innovative and interactive content and delivery. In distance education system, E-learning became a new mantra for delivering higher education courses over really long distances. There are fundamentally two types of E-learning synchronous training and asynchronous training.
\end{abstract}

Keywords: Synchronous training, Asynchronous training, Embedded learning, E-learning, electronic distance education

\section{Introduction}

Synchronous Training: It involves interaction of participant with an instructor via the web in real time.

Asynchronous Training: It is a new form of hearing known as blended learning is emerging.

Synchronous Method: Virtual classroom, duplicates the features of a real classroom online participant interact with each other and instructors online.

Most institutions prefer to use a mix of both synchronous and asynchronous E-learning method according to their requirement.

\section{Asynchronous Method}

1.Embedded learning - Electronic performance support system (EPSS) is a type of embedded learning.

2. Discussion groups - A discussion group is gathering of conversations that occur overtime. They are also called message boards, bulletin boards and discussion from.

3. Courses - Clear advantage of a self paced course id convenience.

\section{Advantage of E-learning}

It improved performance. A 12 years met analysis of research by the U.S. department of education found that higher education student in online learning generally performed better than those in face to face courses.

1. E-learning is convenient and flexible and the learning session are available $25 \times 7$ leanness are free to attain class at any time or place.

2. It enables learners to develop essential skills for knowledge based workers by embedding the use of ICT.

3. Reduce overall training time or need to travel, student studied remain in one location.

4. Spread training out over extended period of time.
5. Students assume the role or active problem solvers, decision makers, and meaning makers rather than passive listeners.

6. Teacher assumes the role of cognitive and met cognitive coach rather than knowledge holder and disseminator.

7. The virtual libraries are providing the multiple references to the students and allowing them to have the interaction with the guides using remote sensing technique.

8. The data mining is helping to categories the student into various ways and to provide customized learning environment to them.

9. By creating e-groups, students use relevant websites, file bin where they can exchange relevant files and documents.

10. It play an active role to enhance capacity building in teacher \& student and make them confident.

\section{Barriers in Electronic Distance Education}

- Inadequate finances

- Absence of clear governmental policies

- Limited use of ICT.

- Lack of interactive counseling session

- Lack of attitude towards using modern ICT in teaching

- Poor communicational and infrastructural facilities.

- Shortage of experts to develop multimedia courses.

- Lack of continuity validity and reliability in technologies.

- Log on problem and graphic incapability.

\section{Future Prospective in E-learning}

- It released pressure both on teacher \& student through online tuition on demand on any subject.

- Future learning promotes E-training programmes to upgrade employees of institution. Which save money and time.

- Future learning promotes E-training programmes to upgrade employees of institution which save money \& time. 


\section{International Journal of Science and Research (IJSR) \\ ISSN (Online): 2319-7064}

Index Copernicus Value (2013): 6.14 | Impact Factor (2014): 5.611

- Blogs are playing a big role in the E-learning environment these days.

- Learner as well as teacher of instructor use blogs for discussion or announcement or knowledge sharing or management etc.

- It helps learner to think and write more critically learners tend to research and study harder when blogs are used.

- Student should experience these technologies as much as possible in the classroom to fully understand how they can be integrated into the various work related operation that exist today.

\section{Suggestions to make easier EDE}

- More study and exam centers should be established in areas, which are nearer to interior villages, so that needy person also facility by EDE.

- Emphasis should be given on practical and creative aspects of life through EDE.

- Adapting new method of assessment and evaluation.

- Electronic distance education programmes should be associated with national and regional policy. It must to think innovatively, Government must be prepared to think innovatively (eg.) broadband models, solar energy wireless, PDAS mixed technology.

- Strategies to strengthen the open distance learning programmes must be based on a detailed and careful analysis of specific situations including the political infrastructure and aspirations of the people, resource bases.

- It is essential to maintain better standard in EDE a continuous monitoring and evaluation of quality.

- Management should commit necessary founds and time on quality of E-learning in distance education.

- Training packages for different cadres/functionaries to motivate the people in organization and process should be open to suggestions from teacher and student.

- EDE succeed only when it will be able to maintain perfect two way communication with the students and for this purpose take all necessary measures.

- WAN (wide area network) to supply or facilitate various course material through the internal to distance learners to get the needy information.

- To establish a WEB BASED LIBRARY for the benefit of distant learners.

- The central \& state government should provide the financial assistance to establish the independent internet service providers (ISP) like VSWL to ODL academic institutions to provide instant very needful information

- By the use of ICT in open \& distance learning the performance of student can be assessed and placement facilities will be better for them through e-portfolio.

- Innovative methods of teaching should be identified. Through open and distance learning teachers are to familiarize for effective use to innovative method

\section{Conclusion}

Given the speed of technological development and the pressure to use technology for its own sake, caution is essential. Nevertheless audio visual media are not sufficiently used in distance teaching, primarily because academics and administrators are generally unaware of their potential, inexperienced in their use or frightened off by their imagined costs.

\section{References}

[1] Amar Nath Rai, 2000, Distance education open learning Vs, Virtual university concepts published by authors press laxmi Nager Delhi 110092, Pg No. 1671.

[2] Anita Sharma, 2010, Distance education global publications, New Delhi 11002, ISBN 9789380833002, Pg No. 187-212.

[3] P. Renga Ramanujam, 2002, Distance open learning challenges to developing countries, published by Shipra Publication Delhi 110092, ISBN 8175410981.

[4] S. K. Panner Selvam, 2009, Distance education in the 21 century, Published by APH publishing corporation, New Delhi 110002, ISBN 9788131306277.

[5] S. Venkatiah editor, 2001, Distance education challenge and response, Anmol publication pvt. Ltd., New Delhi 110002, ISBN 8126107952 